\title{
Self-reported hand contact dermatitis among female hairdressers in Basrah
}

Wasan H. Ghani', Asaad Q. Al-Yassen²

\section{ABSTRACT}

Background: Occupational skin diseases are common and deserve medical attention. Hairdressers are special risky group for skin diseases.

Objective: To determine the prevalence of self-reported hand contact dermatitis among female hairdressers in Basrah city.

Methods: Sixty one salons in Basrah city center were chosen randomly by using the systematic random sampling technique from a name's list of registered salons in Basrah General Health Directorate. A convenient sample of female hairdressers was chosen from these salons.

A special questionnaire form prepared for the purpose of the study was used for collection of data from female hairdressers who agreed to participate in the study by direct interview.

Results: A total of $\mathbf{8 0}$ female hairdressers were included in the study. Their age ranged between 19 and $\mathbf{6 5}$ years old with a median age of $\mathbf{3 2 . 5}$ years. The prevalence of self- reported hand contact dermatitis or eczema among female hairdressers was $31.3 \%$. It was significantly associated with the age and nationality of female hairdressers ( $P$-value $=0.021$ and 0.035 respectively). Furthermore, there was significant association between self- reported hand contact dermatitis and personal history of atopy ( $P$ value $<\mathbf{0 . 0 0 1}$ ) and family history of atopy. (P-value=0.031).

Conclusions: The self- reported hand contact dermatitis is fairly common and associated significantly with age of female hairdressers, nationality, personal and family history of atopy. We recommend to enhance occupational health measures for the hairdressers with special alteration in the preventive aspects Key words: Hairdressers, contact dermatitis, Basrah.

$$
\text { التهاب الجلد التماسي المعلن عنه ذاتيا بين النساء العاملات بمهنة الحلاقة في البصرة }
$$

الخلفية: الأمراض الجلدية المهنية شائعة وتستحق الرعاية الطبية العاملين بمهنة الحلاقة هم اكثر عرضة للإصابة بالأمراض

الهدف من الدراسة: معرفة مدى انتشار التهاب الجلد التماسي لدى العاملات في مهنة الحلاقة في محافظة البصرة

طريقة العمل: اشتملت هذه الدراسة على الף صالون في مركز مدينة البصرة اختيرت عشوائيا من قائمة اسماء الصالونات المسجلة في دائرة صحة فهرة

البصرة.

نتائج الدراسة: العدد الاجمالي للعاملات في مهنة الحلاقة في هذه الدراسة كان • ^ عاملة. العاملات اللواتي تضمنتهن الدراسة تراوحت اعمارهن بين

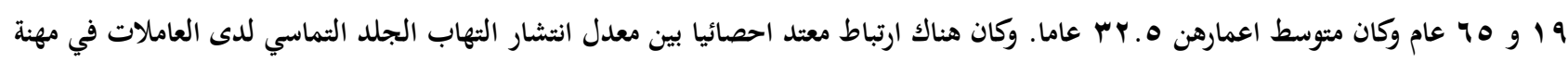

$$
\text { الحلاقة و عمر العاملة) على التوالي. (P P }
$$

وكذلك يوجد ارتباط معتد احصائيا بين نسبة انتشار التهاب الجلد التماسي ووجود التهاب الجلد الاتوبي او في التاريخ العائلي لدى العاملات في مهنة الحلاقة. (P-Value > 0.001 \& 0.031) على التوالي.

الاستنتاجات: نستنتج من هذه الدراسة ان التهاب الجلد التماسي يرتبط بشكل كبير بسنّ العاملات في مهنة الحلاقة وجنسيتهن والتاريخ الشخصي والعائلي للإصابة بالتهاب الجلد الاتوبي. من المهم تعزيز واقع الصحة المهنية للعاملات في مهنة الحلاقة.

${ }^{1}$ MBChB, Department of Family and Community Medicine, College of Medicine, University of Basrah, Iraq

${ }^{2} \mathrm{MBChB}, \mathrm{MSc}$, Assistant Prof. of Dermato-Epidemiology and Occupational Health, Department of Family and Community Medicine, College of Medicine, University of Basrah, Iraq 


\section{INTRODUCTION}

$\mathrm{O}$ ccupational skin diseases are described internationally as the second common group of occupational diseases after musculoskeletal disorders ${ }^{[.1]}$ Contact dermatitis is an important health problem in occupations, affects mostly manual work, and is usually described as a skin reaction caused by frequent contact with irritants or allergens. ${ }^{[2]}$ Hand contact dermatitis forms about $90-95 \%$ of occupational skin diseases. It could be allergic or irritant. The most common type is irritant contact dermatitis, seen in $70-80 \%$ of cases, while allergic contact dermatitis is approximately $20-25 \% .{ }^{[3]}$ Hairdressing is one of the occupations that have been practiced thousands of years. They usually suffer from many occupational problems. ${ }^{[4]}$ Hairdressers are exposed to different chemical compounds that are present in hairstyling and care products. ${ }^{[5]}$ In Iraq and specifically in Basrah, it seems there is shortage in studies handling occupational skin diseases and in particular contact dermatitis among hairdressers.

The study aimed to determine the prevalence of self-reported hand contact dermatitis or eczema among female hairdressers in Basrah city.

\section{METHODOLOGY}

A cross-sectional study conducted during the period from the $1^{\text {st }}$ of January to the $1^{\text {st }}$ of June 2018. Sixty one salons out of 122 salons in Basrah city center were chosen randomly by using the systematic random sampling technique from a list of registered salons in Basrah General Health Directorate. A convenient sample of 80 female hairdressers was chosen from these salons. A special questionnaire form prepared for the purpose of the study was used for collection of data from female hairdressers who agreed to participate in the study by direct interview. The questionnaire included information about personal socio demographic characteristics like name of the salon, age, marital status, educational level, smoking status, place of residency, age of starting job as a hairdresser, years of work as a hairdresser and questions regarding the daily work activities in their salons. Also asked about personal and family history of atopy. In addition, they were asked about the history of having hand contact dermatitis or eczema during the last year. The severity of the dermatitis was determined by asking if they needed for rest and received medical treatment. The data were coded and analyzed using the Statistical Package for the Social Sciences (SPSS) version 20. Significance was tested using chi-square and exact- fisher tests whenever appropriate. A P- value of $<0.05$ was the criterion of statistical significance. ${ }^{[6]}$

\section{RESULTS}

Eighty female hairdressers were involved in this cross sectional study. Their age ranged from 19 to 65 years with a median age of 32.5 years. The majority of them $(65.0 \%)$ were married and $(55.0 \%)$ had intermediate and secondary levels of education. Most of the studied hairdressers are Iraqis $(85.0 \%)$ while non-Iraqi constitute $15.0 \%$. About half of the female hairdressers $(48.7 \%)$ are currently smokers while non-smokers formed about $(51.3 \%)$. Regarding work related characteristics, approximately half $(53.8 \%)$ of the studied population had worked as a hairdresser in their salons for more than 5 years. The majority of them spent 20 - 40 hours per week working in their salons (91.2\%). About half (55.0\%) of female hairdressers frequently washed their hand (More than 20 times per day) when they were working in the salons. During visiting the salon most of the hairdressers insisted on that they used protective measures during work (90.0\%). The percentage of female hairdressers who experienced hand contact dermatitis during the last year was $31.3 \%$. Mainly affected the palms and web spaces of the hands $(76.2 \%)$. Most of them consulted a dermatological clinics and received medical treatment. Forty-one 
percentage of the studied female hairdressers had personal history of atopy and $6.2 \%$ of them had family history of atopy.

In the present study, the self- reported hand contact dermatitis among female hairdressers was significantly associated with the age and nationality of female hairdressers( $\mathrm{P}$ - value $=$ 0.021 and 0.035 respectively). (Table-1), Furthermore, there was significant association between self- reported hand contact dermatitis or eczema and personal history of atopy (P- value $<0.001)$ and family history of atopy. (Pvalue $=0.031)$. (Table-2) However, there was no significant association between the presence of hand contact dermatitis and educational level, smoking status, marital status, years of work as a hairdresser and hours of work in the salons. The results of logistic regression analysis showed that, the personal history of atopy was the only significantly associated with the presence of hand contact dermatitis with an OR, 21.3; 95\% CI, 5.4 - 65.4; $\mathrm{P}<0.001$.

Table 1. The association of self-reported hand contact dermatitis and personal characteristics among female hairdressers

\begin{tabular}{|c|c|c|c|c|c|c|}
\hline \multirow{3}{*}{\multicolumn{2}{|c|}{ Variables }} & \multicolumn{4}{|c|}{ Self- reported hand contact dermatitis } & \multirow{3}{*}{ P- value } \\
\hline & & \multicolumn{2}{|c|}{ Present } & \multicolumn{2}{|c|}{ Absent } & \\
\hline & & No. & $\%$ & No. & $\%$ & \\
\hline \multirow{3}{*}{ Age / years } & $<25$ & 3 & 12.5 & 21 & 87.5 & \multirow{3}{*}{0.021} \\
\hline & $25-40$ & 18 & 45.0 & 22 & 55.0 & \\
\hline & $>40$ & 4 & 25.0 & 12 & 75.0 & \\
\hline \multirow{3}{*}{$\begin{array}{c}\text { Educational } \\
\text { level }\end{array}$} & Illiterate \& primary & 5 & 26.3 & 14 & 73.7 & \multirow{3}{*}{0.839} \\
\hline & $\begin{array}{l}\text { Intermediate } \\
\& \text { secondary }\end{array}$ & 14 & 31.8 & 30 & 68.2 & \\
\hline & Institute \& collage & 6 & 35.3 & 11 & 64.7 & \\
\hline \multirow{3}{*}{ Marital status } & Unmarried & 4 & 19.0 & 17 & 81.0 & \multirow{3}{*}{0.340} \\
\hline & Married & 19 & 36.5 & 33 & 63.5 & \\
\hline & Divorced \& widow & 2 & 28.6 & 5 & 71.4 & \\
\hline \multirow{2}{*}{ Smoking status } & Non smoker & 13 & 31.7 & 28 & 68.3 & \multirow{2}{*}{0.928} \\
\hline & Current smoker & 12 & 30.8 & 27 & 69.2 & \\
\hline \multirow{2}{*}{ Nationality } & Iraqi & 18 & 26.5 & 50 & 73.5 & \multirow{2}{*}{0.035} \\
\hline & Non-Iraqi & 7 & 58.3 & 5 & 41.7 & \\
\hline \multicolumn{2}{|c|}{ Total } & 25 & 31.3 & 55 & 68.7 & \\
\hline
\end{tabular}


Table 2. The association of self- reported hand contact dermatitis or eczema and clinical and occupational profile among female hairdressers

\begin{tabular}{|c|c|c|c|c|c|c|}
\hline \multirow{3}{*}{\multicolumn{2}{|c|}{ Variables }} & \multicolumn{4}{|c|}{ Self-reported hand contact dermatitis } & \multirow{3}{*}{ P- value } \\
\hline & & \multicolumn{2}{|c|}{$\begin{array}{c}\text { Present } \\
\text { Total (25) }\end{array}$} & \multicolumn{2}{|c|}{$\begin{array}{c}\text { Absent } \\
\text { Total (55) }\end{array}$} & \\
\hline & & No. & $\%$ & No. & $\%$ & \\
\hline \multirow[t]{2}{*}{ Years of work } & $\leq 5$ & 8 & 21.6 & 29 & 78.4 & \multirow{2}{*}{0.085} \\
\hline & $>5$ & 17 & 39.5 & 26 & 60.5 & \\
\hline \multirow[t]{3}{*}{ Hours of work / week } & $<20$ & 2 & 28.6 & 5 & 71.4 & \multirow{3}{*}{0.360} \\
\hline & $20-40$ & 16 & 27.6 & 42 & 72.4 & \\
\hline & $>40$ & 7 & 46.7 & 8 & 53.3 & \\
\hline \multirow{3}{*}{$\begin{array}{l}\text { Frequency of hand } \\
\text { washing / day }\end{array}$} & $<10$ & 4 & 26.7 & 11 & 73.3 & \multirow{3}{*}{0.826} \\
\hline & $10-20$ & 6 & 28.6 & 15 & 71.4 & \\
\hline & $>20$ & 15 & 34.1 & 29 & 65.9 & \\
\hline \multirow{2}{*}{$\begin{array}{l}\text { Personal history of } \\
\text { atopy }\end{array}$} & Yes & 21 & 63.6 & 12 & 36.4 & \multirow{2}{*}{0.000} \\
\hline & No & 4 & 8.5 & 43 & 91.5 & \\
\hline \multirow[t]{2}{*}{ Family history of atopy } & Yes & 4 & 80.0 & 1 & 20.0 & \multirow{2}{*}{$0.031 *$} \\
\hline & No & 21 & 28.0 & 54 & 72.0 & \\
\hline
\end{tabular}

*Fisher's Exact Test

\section{DISCUSSION}

Occupational disease is a disease developing primarily as a result of exposure to risk factors arising from work activity. Asian countries do not have an established system of reporting these diseases Hence data regarding epidemiology is scarce. ${ }^{[7]}$ The present study is a cross sectional one, aimed to determine the prevalence of hand contact dermatitis or eczema among female hairdressers in Basrah city. It is considered as the first occupational health study among hairdressers in Iraq. The present study, showed that self- reported history of hand contact dermatitis during the last year was $31.3 \%$. This agreed with other studies, as a cross sectional study done in UK, ${ }^{[6]}$ which showed that prevalence of hand dermatitis was $38.6 \%$ and a cross sectional study done in Nigeria by Douglas, et al (34.3\%). ${ }^{[9]}$ Furthermore, a study was done by Tresukosol, et al. ${ }^{[10]}$ in Bangkok found that the palmer surface of hands and fingers was the most commonly involved site of hand contact dermatitis among hairdressers (38.0\%). Nevertheless, in the present study more than two thirds of the female hairdressers who had hand contact dermatitis predominantly affect the palmer surfaces and web spaces. Thirty six percent of female hairdressers had personal history of atopy in a study in Denmark. $^{[11]}$ This is in agreement with the present study in which the percentage of female hairdressers who had a personal history of atopy was $41.3 \%$. However, a polish study found that $15.8 \%$ had atopy. ${ }^{[12]}$ The present study found that $6.2 \%$ of female hairdressers had family history of atopy in contrast with a study in Saudi Arabia which observed that $56.3 \%$ of female hairdressers with contact dermatitis had family history of allergy. ${ }^{[13]}$ A cross sectional study was carried out by Perkins, et al. ${ }^{[8]}$ in UK realized that age of hairdressers was 
significantly associated with high prevalence of hand contact dermatitis $(\mathrm{P}=0.01)$ and this result is consistent with the results of this study ( $\mathrm{P}$ value $=0.021)$. The relationship between educational level of female hairdressers and prevalence of self-reported hand contact dermatitis in the present study was insignificant $(P-$ value $=0.839)$ and this was agrees with other study. ${ }^{[14]}$ Additionally, there was no significant association in the present study between hand contact dermatitis and smoking status among female hairdressers. A result which, is in agreement with that reported by Bregnhoj, et al study ${ }^{[15]}$ and an Iranian study. ${ }^{[14]}$ Furthermore, there was significant association between contact dermatitis with nationality of female hairdressers by univariate analysis that was disagreed with a study which was carried out by Lestringant, et al in UAE. ${ }^{[16]}$ A study was done by Caroe, et al. among Danish female hairdressers showed a significant association between atopic dermatitis and hand eczema ( $\mathrm{P}$ value $<0.002) .{ }^{[11]}$ as in the present study, $(\mathrm{P}$ value $<0.001)$. The finding supports the idea that atopic dermatitis significantly influences the development of hand eczema. Atopics have an irritable skin that is vulnerable to common irritants like soaps, detergents, environmental factors like hot humid weather, which can precipitate the disease. ${ }^{[11]}$

In the present study, there was a significant association between family history of atopy and hand contact dermatitis (only by univariate analysis $(\mathrm{P}$-value $=0.031)$ and this was reported by a study in Saudi Arabia in which hairdressers who had family history of any allergy had complained of hand dermatitis or eczema, $(\mathrm{P}=$ $0.006)^{[13]}$ There was no significant association between the prevalence of hand contact dermatitis among female hairdressers with years of work as a hairdresser in a salon, hours of works per week in the salon, frequency of hand washing and marital status.

\section{CONCLUSION}

The study showed that approximately one third of the studied female hairdressers were complaining from hand contact dermatitis. The age of female hairdressers, nationality, personal and family history of atopy were associated significantly with hand contact dermatitis. We recommend to enhance occupational health measures for the hairdressers with a special attention to preventive aspects like health education and periodic health examination. Health education should emphasis the effect of hazardous materials and how to prevent the adverse effects of such hazards.

\section{LIMITATION OF THE STUDY}

The diagnosis of hand contact dermatitis or eczema depended on self- reported history of acquiring dermatitis or eczema this mainly depends on their memory and associated with possibility of in accurate diagnosis.

\section{REFERENCE}

1. Behroozy A, Keegel T G. Wet work exposure: A main risk factor for occupational hand dermatitis. Safety and Health at Work Journal. 2014; 5: 175-180.

2. Chen YX, Cheng HY, Li L F. Prevalence and risk factors of contact dermatitis among clothing manufacturing employees in Beijing A crosssectional study.Medicine.2017; 96:12.

3. Lyons G, Roberts H, Palmer A, Matheson M, Nixon R. Hairdressers presenting to an occupational dermatology clinic in Melbourne, Australia. Contact Dermatitis.2013; 68:300-306.

4. Mendes A, Madureira J, Neves P, Carvlhais C, Laffon B, Teixeira J P. Chemical Exposure and Occupational Symptoms Among Portuguese Hairdressers. Journal of Toxicology and Environmental Health, Part A.2011;74:993-1000.

5. Foss-skiftesvik $M \mathbf{H}$, Winther $L$, Johnsen $C$, Zachariae $C$, Johansen JD. Incidence of skin and respiratory diseases among Danish hairdressing apprentices. Contact Dermatitis. 2017; 76(3):160-166.

6. Bradford HA. Short textbook of medical statistics. Eleventh edition. London Mel borne. Auckland. Edward arnold . 1989 : 12-30. 
7. Bhatia R, Sharma VK. Occupational dermatoses: An Asian perspective. Indian J Dermatol Venereol Leprol. 2017; 83 (5): 525-535.

8. Perkins JB, Farrow A. Prevalence of occupational hand dermatitis in U.K. hairdressers. International Journal of Occupational and Environmental Health. 2005; 11:289-293.

9. Douglas KE, Agbi JO, Akpovienehe O, Etukudo AJ. Occupational hand dermatitis among hairdressers in a semi urban community in River State, South-South Nigeria. The Nigerian Health Journal.2013; 13(3): 125-130.

10. Tresukosol $P$, Swasdivanich C. Hand contact dermatitis in hairdressers: clinical and causative allergens, experience in Bangkok. Asian Pac J Allergy Immunol. 2012; 30:306-312.

11. CaroeTK., Ebbehoj NE, Agner T. Occupational dermatitis in hairdressers-influence of individual and environmental factors. Contact Dermatitis. 2017; 76 (3):146- 150.

12. Krecisz B, Kiec-Swiercynaska $M$, Chomiczewshka D. Dermatological screening and results of patch testing among Polish apprentice hairdressers. Contact Dermatitis. 2011; 64:90-95.
13. Alliali A, Bardisi S, Magliah T. Prevalence and determinants of hand eczema among female hairdressers in Makkah and Jeddah cities, Saudi Arabia. International Journal of Dermatology \& Cosmetic Sciences.2015; 1(1):4-7. 14. Hajaghazadeh M, Jafari A, Jafari S, Hekmmatirad S, Didarloo A. The Prevalence of Hand Eczema and Its Determinants Among Female Hairdressers: A Cross-Sectional Survey. The Open Public Health Journal. 2018; 11: 170176.

15. Bregnhoj A, Menne T, Johansen JD, Sosted H. Prevention of hand eczema among Danish hairdressing apprentices: an intervention study. Occupational Environ Med. 2012; 69: 310-316.

16. Lestringant GG, Bener A, Sawaya M, Galadari IH, Frossard PM. Allergic contact dermatitis in the United Arab Emirates. International Journal of Dermatology.1999; 38: 181-186. 